\title{
Effects of dietary fatty acids on the reproduction of South American female catfish Rhamdia quelen (Quoy \& Gaimard, 1824)
}

\author{
Cleonice Cristina Hilbig ${ }^{1,2}$, Nivaldo Ferreira do Nascimento ${ }^{2}$, Adriano Luis Heinen ${ }^{3}$ \\ Aldo Tovo Neto ${ }^{2}$, Jackson Pablo Funghetto ${ }^{3}$, Robie Allan Bombardelli ${ }^{3}$ \\ Fábio Meurer ${ }^{4} \&$ Laura Satiko Okada Nakaghi ${ }^{2}$ \\ ${ }^{1}$ Universidade Federal da Grande Dourados, Dourados, MS, Brasil \\ ${ }^{2}$ Centro de Aquicultura da UNESP (CAUNESP), Universidade Estadual Paulista, São Paulo, Brasil \\ ${ }^{3}$ Universidade Estadual do Oeste do Paraná, Toledo, PR, Brasil \\ ${ }^{4}$ Universidade Federal do Paraná, Jandaia do Sul, PR, Brasil \\ Corresponding author: Cleonice Cristina Hilbig (cleonicehilbig@ufgd.edu.br)
}

\begin{abstract}
The effects of a diet supplemented with 5\% marine fish oil, 5\% refined palm oil, 5\% soybean oil, and a combination of the three on reproductive parameters of females Rhamdia quelen was investigated. Spawning was artificially induced to evaluate rates of fertilization, hatching and larvae normality. Fatty acid profiles of the diets, ovaries and oocytes were determined. A higher spawning rate (\%) was observed for diets containing fish oil $(78.65 \pm 3.60)$ and palm oil $(77.15 \pm 3.97)$, followed by oil mix $(65.46 \pm 4.57)$. The diet containing soybean oil was associated with significantly lower fertilization $(60.14 \pm 5.66 ; P<0.05)$ than the palm and fish oil diets. Lower fertilization may be explained by a high level of n- 6 fatty acids in the diet, which possibly accelerate the oocyte maturation. Satisfactory fecundity $(P>0.05)$ were observed for all tested diets, whit $289.77 \pm 23.90$ (palm oil) until $323.31 \pm 38.45$ oocytes $\mathrm{g}^{-1}$ body weight (fish oil). The treatments were not shown to influence oocyte size, larval size or rate of larva deformity. Oocyte fatty acid composition was like that of gonads. Docosahexaenoic (DHA; C22:6 n-3) fatty acid was preferentially deposited in ovaries and oocytes. Ratios of n3/n6, DHA/EPA, EPA/ARA, did not affect the reproductive performance of females. Therefore, regarding female reproductive performance, the vegetable lipid sources tested are suitable for being used in $R$. quelen diet, and palm oil, in particular, is considered an excellent alternative to fish oil.
\end{abstract}

Keywords: broodstock; lipid sources; puberty; fecundity; spawning; aquaculture

\section{INTRODUCTION}

Fish oil is considered the best source of fatty acids for commercial aquaculture feeds, but its financial and environmental costs challenge its use for nutrition and production of freshwater fish (Turchini et al., 2009). Vegetable oil has been used for sustainable partial or complete replacement of fish oil in some fish diets, including for broodstock nutrition (Babalola et al., 2011).

Marine fish oils have high concentrations of docosahexaenoic (DHA; C22:6 n-3) and eicosapentaenoic (EPA; C20:5 n-3) acids as well as considerable levels of arachidonic acid (ARA; C20:4 n-6), none of which are present in vegetable oils (Bell \& Sargent, 2003). These long-chain poly-unsaturated fatty acids
(PUFAs) are necessary for normal fish growth (Izquierdo et al., 2001) and regulate responses to the steroid hormones that influence gonad development, sexual maturation and the reproductive cycle (Navas et al., 1998; Zhang et al., 2013).

Although not present in vegetable oils, ARA, EPA and DHA can be produced by freshwater fish from their fatty acid precursors, linoleic (LA, C18:2n-6) and linolenic (LNA, C18:3n-3) acids. Most freshwater fish can convert LA into ARA, and LNA into EPA and, subsequently, DHA, through a series of elongations and desaturations (Sargent et al., 2002; Turchini et al., 2006). However, competitive interactions can occur between LA and LNA, because they compete for the enzymes involved in the biosynthesis of ARA, EPA and DHA (Sargent et al., 1999). The ratio of n3/n6 fatty acids

Corresponding editor: Jesús Ponce Palafox 
in broodstock diet must also be considered (Furuita $e t$ al., 2007), as fatty acid ratios (EPA/ARA/DHA, n3/n6) directly affect the composition and quality of eggs in a species-specific manner (Ng \& Wang, 2011).

Palm oil is considered a potential alternative to fish oil (Aysi \& Zhao, 2014). It has been reported that tilapia Oreochromis niloticus receiving palm oil diets showed earlier first spawning, a shorter inter-spawning interval, a more extended period of broodfish fertility, higher total egg production, higher hatching rates and reduced larval deformities compared to broodfish fed a fish oil based diet (Ng \& Wang, 2011). Soybean oil, on the other hand, is the world's second most commonly produced oil (Aysi \& Zhao, 2014). Liang et al. (2014), mixing fish and soybean oil, proportions of 2.2:1, respectively, in diets for tongue sole Cynoglossus semilaevis obtained higher rates of fertilization, higher survival and lower larva abnormalities. The ready availability and low cost of palm and soybean oil make them promising alternatives to fish oil.

The South American catfish Rhamdia quelen (Quoy \& Gaimard, 1824) is an important aquaculture species in temperate and subtropical South America (Ittzés et al., 2014). It can efficiently convert C18 n-3 and n-6 fatty acids into the long-chain PUFAs ARA, EPA and DHA when fed vegetable oil (Vargas et al., 2014). $R$. quelen reaches sexual maturity at 12 months, and oocyte development is asynchronous, with fractional spawning (Ghiraldelli et al., 2007). The natural breeding period is August to March in southern Brazil (Gomes et al., 2000).

Few studies (Coldebella et al., 2013) focusing on fatty acids profiles of ovaries and eggs of $R$. quelen have been conducted using soybean oil at different levels of inclusion. The present study compared the effects of diets based on fish oil and those supplemented with soybean or palm lipids, alone and in combination with fish oil, on the growth, reproductive performance, and the fatty acid composition of ovaries and oocytes in South American catfish in their first reproductive cycle.

\section{MATERIALS AND METHODS}

\section{Ethics}

The ethics committee on the use of animals of the Paulista State University approved the experimental protocol no 6728/12. The study took place at the Instituto de Pesquisa em Aquicultura Ambiental (INPAA), Universidade Estadual do Oeste do Paraná,

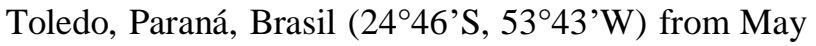
2013 to April 2014.

\section{Experimental diets}

Four isoproteic and isocaloric diets containing 38\% crude protein and 5\% lipids were formulated: $5 \%$ of marine fish oil, 5\% palm oil, 5\% soybean oil, and a combination of the three (MIX) (Table 1). Experimental diets were extruded in an Exteec extruder and dried under forced ventilation at $55^{\circ} \mathrm{C}$ for $12 \mathrm{~h}$, producing $4 \mathrm{~mm}$ pellets. After weighing, oils were gradually added over 30 min using a rotating mixer. The fatty acid composition of the diets was analysed at the Instituto de Tecnologia de Alimentos, ITALCampinas/São Paulo, using the methods of Zenebon \& Pascuet (2005) for total lipid extraction, and Horwitz et al. (2005) and Firestone (2014) for fatty acid profile (Table 2).

\section{Fish and experimental design}

Two-thousand juveniles of Rhamdia quelen at 60 days post-hatching (dph) of mixed-sex obtained from a commercial fishery were distributed among 20 outdoor $12 \mathrm{~m}^{2}$ concrete tanks (water volume of approximately $9.3 \mathrm{~m}^{3}$ and depth of $100 \mathrm{~cm}$ ), 100 fish/tank. The mean \pm SE (standard error) initial weight of the fish was $24.50 \pm 0.78 \mathrm{~g}$, total length $14.10 \pm 0.41 \mathrm{~cm}$ and standard length $11.54 \pm 0.26 \mathrm{~cm}$, with no significant differences $(P>0.05)$ among tanks.

The fish were randomly assigned to one of the four diet groups, five tanks per diet. Fish were fed twice daily, at 10:00 and 16:00 h, and were weighed and measured monthly to adjust the feeding rate to $2 \%$ of body weight $\mathrm{d}^{-1}$. In October 2013, 270 dph, sexual dimorphism was evident from external features and the ease with which sperm could be obtained through hand stripping. Twenty females from each tank (total 400) were randomly selected, weighed, measured (total length) and transferred (keeping treatments units) to each of $204 \times 2 \times 1 \mathrm{~m}$ cages in $800 \mathrm{~m}^{2}$ tanks $(20$ females/cage) with good water circulation, which not required artificial aeration. Feeding continued at $2 \%$ of body weight $\mathrm{d}^{-1}$ for another six months.

Water temperature was monitored twice daily, morning $\left(17.45 \pm 1.82^{\circ} \mathrm{C}\right)$ and afternoon $(27.20 \pm$ $1.16^{\circ} \mathrm{C}$ ) with the YSI $550 \mathrm{~A}$. The dissolved oxygen $($ YSI $550 \mathrm{~A})$ and $\mathrm{pH}$ levels $\left(\mathrm{Tecnal}^{\circledR} \mathrm{Tec} 5\right)$ were recorded weekly, at 06:00 h: $5.64 \pm 0.15 \mathrm{mg} \mathrm{L}^{-1}$ and $7.11 \pm 0.04$; and at 16:00 h: $6.67 \pm 0.16 \mathrm{mg} \mathrm{L}^{-1}$ and 7.37 \pm 0.08 , respectively. Ammonia levels were checked monthly $\left(0.03 \pm 0.01 \mathrm{mg} \mathrm{L}^{-1}\right)$ by colorimetry (Koroleff, 1976).

\section{Spawning and sampling}

In February 2014, five females exhibiting a rounded abdomen, reddish protruding urogenital papillae and 
Table 1. Formulation and mean values of the composition of experimental diets (dry matter). ${ }^{1}$ Basic composition: vitamin A: 1,000,000 UI kg ${ }^{-1}$, vitamin D3: 500,000 UI kg-1; vitamin E: 20,000 UI kg-1 vitamin K3: $500 \mathrm{mg} \mathrm{kg}^{-1}$; vitamin B1: 1,900 mg kg-1 ; vitamin B2: 2,000 mg kg-1; vitamin B6: $2,400 \mathrm{mg} \mathrm{kg}^{-1}$; vitamin B12: $3,500 \mathrm{mg} \mathrm{kg}^{-1}$; vitamin C $50 \mathrm{~g} \mathrm{~kg}^{-1}$; Niacin: 5,000 mg kg-1; Pantothenic acid: 4,000 mg kg-1; Folic acid: $200 \mathrm{mg} \mathrm{kg}^{-1}$; Biotin: $40 \mathrm{mg} \mathrm{kg}^{-1}$; Manganese: 7,500 mg kg Zinc: $25 \mathrm{~g} \mathrm{~kg}^{-1}$; Iron: $12.5 \mathrm{~g} \mathrm{~kg}^{-1}$; Copper sulphate: $2,000 \mathrm{mg} \mathrm{kg}^{-1}$; Iodine: $200 \mathrm{mg} \mathrm{kg}^{-1}$; Selenium: $70 \mathrm{mg} \mathrm{kg}^{-1}$ BHT $300 \mathrm{mg}$ $\mathrm{kg}^{-1}{ }^{2}$ Weende analysis carried in Laboratório de nutrição Animal (LANA-Unesp Jaboticabal-SP). SO: diet containing soybean oil; PO: diet containing refined palm oil; FO: diet containing marine fish oil; MIX: diet containing a combination of the three oils.

\begin{tabular}{lrrrr}
\hline \multirow{2}{*}{ Ingredients g kg $^{-1}$} & \multicolumn{4}{c}{ Experimental diets } \\
\cline { 2 - 5 } & \multicolumn{1}{c}{$\mathrm{SO}$} & \multicolumn{1}{c}{ PO } & \multicolumn{1}{c}{ FO } & \multicolumn{1}{c}{ MIX } \\
\hline Soybean meal & 300.00 & 300.00 & 300.00 & 300.00 \\
Maize (ground grain) & 255.60 & 255.60 & 255.60 & 255.60 \\
Salmon meal & 200.00 & 200.00 & 200.00 & 200.00 \\
Wheat gluten & 93.60 & 93.60 & 93.60 & 93.60 \\
Dicalcium phosphate & 75.71 & 75.71 & 75.71 & 75.71 \\
Soybean oil & 50.00 & - & - & 16.60 \\
Refined palm oil & - & 50.00 & - & 16.60 \\
Fish oil & - & - & 50.00 & 16.60 \\
Premix ${ }^{1}$ & 20.00 & 20.00 & 20.00 & 20.00 \\
Salt (NaCl) & 5.00 & 5.00 & 5.00 & 5.00 \\
BHT (antioxidant) & 0.20 & 0.20 & 0.20 & 0.20 \\
Fungicide (propionic acid) & 0.01 & 0.01 & 0.01 & 0.01 \\
\hline Nutrients (\%) & & & & \\
Dry matter & 95.62 & 95.11 & 93.49 & 96.35 \\
Crude protein & 38.46 & 38.51 & 37.92 & 38.84 \\
Ether extract & 6.36 & 7.74 & 7.20 & 6.07 \\
Crude fiber & 1.72 & 2.61 & 2.19 & 2.27 \\
Ash & 12.93 & 12.93 & 12.81 & 13.20 \\
Nitrogen-free extract & 36.15 & 33.32 & 33.37 & 35.97 \\
\hline
\end{tabular}

uniform oocyte size, indicating reproductive maturity, were selected from each cage and transferred to 20 fiberglass tanks of $500 \mathrm{~L}$ for artificial insemination (n $\left.=100,5 \operatorname{tank}^{-1}\right)$. Tanks were maintained in a recirculation system with mean water temperature of $26.5 \pm$ $1.5^{\circ} \mathrm{C}$ and dissolved oxygen of $5.5 \pm 1.0 \mathrm{mg} \mathrm{L}^{-1}$.

Ovulation was synchronized with carp pituitary extract (CPE) in an initial injection of $0.5 \mathrm{mg} \mathrm{kg}^{-1}$ body weight, followed by a second injection of $5.0 \mathrm{mg} \mathrm{kg}^{-1}$ body weight $12 \mathrm{~h}$ later (Bombardelli et al., 2006). Oocytes were collected by gently squeezing the female abdomen at 240 degree-h ( $10 \mathrm{~h}$ with water temperature at $24^{\circ} \mathrm{C}$ ) after the second injection. The oocyte mass released by each female was weighed to $0.01 \mathrm{~g}$ using an analytic scale (Marte ${ }^{\circledR}$ AS2000C), and an aliquot of 0.1 g (analytic scale Marte ${ }^{\circledR}$ AY220, 0.0001 g accuracy) was fixed in Karnovisky solution to determine the number of oocytes $\mathrm{g}^{-1}$, absolute fecundity (total number of oocytes released), relative fecundity (number of oocytes released relative to body weight) and size of oocytes.

Fifty-gram samples of oocytes released by the females $(n=5)$ in each cage were combined, placed in plastic bags, labeled and stored at $-18^{\circ} \mathrm{C}$ until analysis of fatty acids.

One year old South American catfish males, obtained from the Instituto de Pesquisa em Aquicultura Ambiental, were stocked separately from the females into $200 \mathrm{~m}^{2}$ excavated masonry-lined ponds (water volume of approximately $300 \mathrm{~m}^{3}$ ) with an earth bottom and fed a commercial diet (28\% crude protein). The males were injected with a single dose of $3.0 \mathrm{mg} \mathrm{kg}^{-1}$ bodyweight $\mathrm{CPE}$ at the time of the second female hormone injection. Semen was stripped from 20 males by gentle abdominal pressure and collected into graduated test tubes $( \pm 0.1 \mathrm{~mL})$. Approximately $2 \mathrm{~mL}$ of semen from each male was used to create five pools, each comprising semen of four males. A sample of each pool was used to determine spermatozoon concentration (Neubauer chamber, 1:1,000 semen: formalin), and spermatozoon motility (Computer-Assisted Sperm Analysis) according to Sanches et al. (2010).

The quality of the semen pools was satisfactory concerning mean volume, spermatozoon concentration and motility (Table 3$)$. Each semen pool $(n=5)$ was used to fertilize eggs of females of four tanks, each one 
Table 2. Fatty acid profile (\% of total FA) of the diet containing different lipid sources fed to Rhamdia quelen females. ${ }^{1}$ Analyzes carried out in the Centro de Ciência e Qualidade de Alimentos-ITAL, Campinas/São Paulo. SO: diet containing soybean oil, PO: diet containing refined palm oil, FO: diet containing marine fish oil, MIX: diet containing a combination of the three oils.

\begin{tabular}{|c|c|c|c|c|}
\hline \multirow{2}{*}{ Fatty acid $(\%)^{1}$} & \multicolumn{4}{|c|}{ Diets } \\
\hline & $\mathrm{SO}$ & $\mathrm{PO}$ & FO & MIX \\
\hline C12:0 & 0.00 & 0.21 & 0.11 & 0.11 \\
\hline C14:0 & 0.45 & 0.97 & 2.13 & 1.20 \\
\hline C15:0 & 0.00 & 0.11 & 0.34 & 0.11 \\
\hline C16:0 & 13.86 & 29.43 & 18.61 & 21.24 \\
\hline $\mathrm{C} 17: 0$ & 0.11 & 0.11 & 0.34 & 0.22 \\
\hline C18:0 & 3.98 & 4.19 & 3.92 & 4.03 \\
\hline C 20:0 & 0.34 & 0.32 & 0.34 & 0.33 \\
\hline $\mathrm{C} 22: 0$ & 0.34 & 0.11 & 0.11 & 0.22 \\
\hline $\mathrm{C} 24: 0$ & 0.00 & 0.75 & 0.00 & 0.00 \\
\hline$\sum$ Saturated & 19.09 & 36.20 & 25.90 & 27.45 \\
\hline C16:1n7 & 0.57 & 0.64 & 4.15 & 1.74 \\
\hline C $17: 1$ & 0.00 & 0.00 & 0.22 & 0.11 \\
\hline C18:1n9 & 28.30 & 37.92 & 28.48 & 31.37 \\
\hline C20:1n11 & 0.45 & 0.43 & 0.90 & 0.54 \\
\hline C22:1 & 0.00 & 0.00 & 0.11 & 0.00 \\
\hline C24:1 & 0.34 & 0.21 & 0.34 & 0.22 \\
\hline$\Sigma$ Mono-unsaturated & 29.66 & 39.21 & 34.19 & 33.99 \\
\hline C18:2n6 & 43.18 & 20.62 & 23.21 & 28.87 \\
\hline C18:3n3 & 3.86 & 1.50 & 2.91 & 2.83 \\
\hline $\mathrm{C} 20: 2 \mathrm{n} 6$ & 0.23 & 0.21 & 0.45 & 0.33 \\
\hline C20:3n6 & 0.11 & 0.11 & 0.22 & 0.11 \\
\hline C20:3n3 & 0.00 & 0.00 & 0.11 & 0.11 \\
\hline C20:5n3 (EPA) & 0.68 & 0.00 & 2.58 & 1.31 \\
\hline C 22:6n3 (DHA) & 1.02 & 0.97 & 3.81 & 1.85 \\
\hline $\mathrm{C} 22: 5 \mathrm{n} 3$ & 0.23 & 0.32 & 0.90 & 0.44 \\
\hline$\Sigma$ Poly-unsaturated & 49.32 & 23.74 & 34.19 & 35.84 \\
\hline$\Sigma$ Omega 3 & 5.80 & 2.79 & 10.31 & 6.54 \\
\hline$\Sigma$ Omega 6 & 43.41 & 20.84 & 23.65 & 29.19 \\
\hline$n-3 / n-6$ & 0.13 & 0.13 & 0.44 & 0.22 \\
\hline Total lipids $\left(\mathrm{g} 100^{-1} \mathrm{~g}\right)$ & 9.17 & 9.73 & 9.33 & 9.61 \\
\hline
\end{tabular}

from a different treatment. A standard insemination dose of $100 \mu \mathrm{L}$ of semen was used to fertilize $2 \mathrm{~mL}$ $(3,496.96 \pm 115.38)$ of oocytes from each female. Gamete activation was conducted in $150 \mathrm{~mL}$ plastic containers with $20 \mathrm{~mL}$ of water. After activation, eggs were hydrated for $1 \mathrm{~min}$ during fertilization and, subsequently, incubated in 100 conical incubators of $2.5 \mathrm{~L}$ each, in a recirculating water system equipped with mechanical and biological filtration at a water temperature of $27 \pm 1.0^{\circ} \mathrm{C}$ maintained by electrical heating.

Eleven hours post-fertilization (hpf), after blastopore closure, fertilized eggs (translucent with apparent normal embryonic development) and non-fertilized eggs (white and opaque) were counted. The fertilization rate (FR) was determined in three sub-samples of $~ 135$ eggs from each incubator using the equation: FR $(\%)=$ number of viable oocytes $\times 100 /$ total number of eggs.

At $36 \mathrm{hpf}$, all larvae were removed from the incubators and fixed in Karnovisky solution. Larval deformity rate was determined by examining 300 larvae with a stereomicroscope (Leica DMZ 180) and classifying them as normal according to De Amorim et al. (2009), or abnormal. All fixed larvae were counted to determine the hatching rate (HR) using the equation: $\mathrm{HR}=$ [number of hatched larvae / (number of eggs in 2 $\mathrm{mL}$ - the number of eggs used for calculating FR) $\times$ 100].

A stereomicroscope (Nikon, SMZ 1500, Tokyo, Japan) equipped with a camera (DS-Fi, Nikon, Japan) was used to obtain digital images of oocytes and fixed larva, and size was determined using Nis-elements 
Table 3. Characteristics of Rhamdia quelen sperm pools used for fertilization. SPZ $\mathrm{mL}^{-1}$ : spermatozoa per millilitre.

\begin{tabular}{crccc}
\hline $\begin{array}{c}\text { Pool } \\
\mathrm{n}=4\end{array}$ & Weight $(\mathrm{g})$ & Volume $(\mathrm{mL})$ & $\begin{array}{c}\text { Concentration } \\
(\mathrm{SPZ} \mathrm{mL})\end{array}$ & $\begin{array}{c}\text { Motility } \\
(\%)\end{array}$ \\
\hline 1 & $132.52 \pm 20.51$ & $6.42 \pm 3.00$ & $8.50 \times 10^{9}$ & 60.53 \\
2 & $113.80 \pm 17.20$ & $5.50 \pm 0.57$ & $1.85 \times 10^{10}$ & 81.79 \\
3 & $86.67 \pm 27.94$ & $2.57 \pm 0.94$ & $1.96 \times 10^{10}$ & 87.81 \\
4 & $123.57 \pm 20.52$ & $6.52 \pm 4.03$ & $1.83 \times 10^{10}$ & 69.38 \\
5 & $85.00 \pm 25.67$ & $5.07 \pm 0.97$ & $6.20 \times 10^{9}$ & 84.50 \\
\hline
\end{tabular}

Advanced Research software (Nikon, Japan). The diameter of 10 oocytes and the total length of 10 larvae from each female were recorded. Before spawning, two females from each cage sacrificed in benzocaine at 0.75 $\mathrm{mg} \mathrm{L}{ }^{-1}$. After the samples of the ovaries were labeled and immediately frozen at $-18^{\circ} \mathrm{C}$ for fatty acids analysis.

\section{Fatty acid analysis}

The fatty acid composition of the ovaries and oocytes was analyzed at the Laboratório de Bioquímica de Microorganismos e plantas da Universidade Estadual Paulista, Jaboticabal-SP. The fatty acids were measured using the total lipid extraction method of Bligh \& Dyer (1959) and the official methylation method Ce2-66: Preparation of methyl esters of long chain fatty acids firestone (2009).

The fatty acid profiles were analyzed using a gas chromatograph CG-14B (Shimadzu) with fused silica capillary column OMEGAWAX250 $(30 \mathrm{~m} \times 0.25 \mathrm{~mm}$ $\times 0.25$ um, catalog $\left.\mathrm{N}^{\circ} 24136-\mathrm{SUPELCO}\right)$. The column temperature was set at $100^{\circ} \mathrm{C}$ for $2 \mathrm{~min}$ and heated at a rate of $4^{\circ} \mathrm{C} \mathrm{min}-1$ to $220^{\circ} \mathrm{C}$, and held for $25 \mathrm{~min}$. The injector and detector temperatures were 250 and $280^{\circ} \mathrm{C}$, respectively. The carrier gas $\left(\mathrm{H}_{2}\right)$ flow rate was $1 \mathrm{~mL}$ $\min ^{-1}$ (SPLIT: $1 / 100$ ), the volume injected was $1 \mu \mathrm{L}$, using a flame ionization detector. The standard used for fatty acid identification was the Sigma fatty acid standard, catalog $\mathrm{N}^{\circ} 189-19$, and 47015-U.

\section{Statistical analysis}

The study employed a completely randomized design, and data were checked for homogeneity using the Levene's test (Brown \& Forsythe, 1974) and for normality using the Cramer-von Mises test (Darling, 1957). Afterward, the data were analyzed by ANOVA, followed by Tukey's test for multiple comparisons, using Statistica v.10.0 (Statsoft, Tulsa, USA). Significance was considered at $P<0.05$.

\section{RESULTS}

\section{Reproductive performance}

All the females subjected to hormone treatment released oocytes. In 25 per diet group, spawning with successful development was observed in 23 fish in the palm oil group (92\%), 17 in the soybean (68\%) and 15 for mixed and fish oil groups (60\%) (Table 4).

Diets showed a significant effect only on the fertilization rate. The best results were obtained for diets containing fish oil $(78.65 \pm 3.60)$ and palm oil (77.15 \pm 3.97$)$, followed by oil mix $(65.46 \pm 4.57)$. The diet containing soybean oil was associated with significantly lower fertilization $(60.14 \pm 5.66 ; P<0.05)$ than the palm and fish oil diets. Diet had no significant effect $(P>0.05)$ on absolute and relative fecundity, hatching rate, oocyte and larval size, or deformity rate (Table 4).

\section{The total fatty acid composition of gonads and oocytes}

The diet of South American catfish females (Table 2) was reflected in the fatty acid composition of ovary and oocytes, which varied significantly $(P<0.05)$ among diet groups (Tables 5-6).

Oocyte fatty acid composition was like that of gonads. There were significant differences among diets $(P<0.05)$ in the total levels of saturated, mono- and poly-unsaturated fatty acids. Fish receiving the palm oil diet had significantly higher $(P<0.05)$ levels of saturated and monounsaturated fatty acids in gonads and oocytes, with palmitic acid, C16:0, and oleic acid, 18:1n-9, being the most prevalent. The highest levels of total $n-3$ fatty acids were observed in the ovaries and oocytes of the fish oil groups at 15.8 and $15.2 \%$, respectively, and, consequently, higher levels of EPA and DHA were also present. Arachidonic acid was present in significantly higher quantities in the ovaries and oocytes of the soybean oil group $(P<0.05)$ than in the fish and mixed oil groups. Total n- 6 fatty acids (24.6\% in the ovary and $24.3 \%$ in oocytes) were significantly higher $(P<0.05)$ in the soybean oil group.

The lowest $\mathrm{n} 3 / \mathrm{n} 6$ ratio was observed in the liver, ovaries and oocytes of the soybean oil group. The mixed oil diet resulted in a balance of the fatty acids. Fish oil was associated with an increase in EPA, DHA, and n-3 acids and soybean oil increased the level of n6 fatty acids (18\%). 
Table 4. Reproductive and larval characteristics of female Rhamdia quelen fed diets containing different lipid sources, soybean, palm, marine fish and a blend of three oils (MIX). ${ }^{1}$ Mean weight of spawning females; ${ }^{2}$ number of oocytes female ${ }^{-1}$; ${ }^{3}$ oocytes $\mathrm{g}^{-1}$ body weight. Different letters in a row indicate a significant difference $(P<0.05)$. SO: diet containing soybean oil; PO: diet containing refined palm oil; FO: diet containing marine fish oil; MIX: diet containing a combination of the three oils. *No statistical analysis was performed.

\begin{tabular}{lcccc}
\hline \multirow{2}{*}{ Parameters } & \multicolumn{4}{c}{ Diets } \\
\cline { 2 - 5 } & SO & PO & FO & MIX \\
\hline Spawning $(\%)^{*}$ & 68.00 & 92.00 & 60.00 & 60.00 \\
${\text { Weight }(\mathrm{g})^{1}}_{\text {Absolute fecundity }^{2}}$ & $333.21 \pm 37.44^{\mathrm{a}}$ & $318.91 \pm 11.85^{\mathrm{a}}$ & $297.05 \pm 21.90^{\mathrm{a}}$ & $300.47 \pm 26.35^{\mathrm{a}}$ \\
Relative fecundity $^{3}$ & $31.11 \pm 0.21 \times 10^{5 \mathrm{a}}$ & $0.92 \pm 0.06 \times 10^{5 \mathrm{a}}$ & $0.94 \pm 0.16 \times 10^{5}$ & $0.98 \pm 0.12 \times 10^{5 \mathrm{a}}$ \\
Oocyte size $(\mu \mathrm{m})$ & $880.28 \pm 5.32^{\mathrm{a}}$ & $289.77 \pm 23.90^{\mathrm{a}}$ & $323.31 \pm 38.45^{\mathrm{a}}$ & $312.68 \pm 13.76^{\mathrm{a}}$ \\
Fertilization $(\%)$ & $60.14 \pm 5.66^{\mathrm{b}}$ & $881.81 \pm 7.04^{\mathrm{a}}$ & $892.01 \pm 4.37^{\mathrm{a}}$ & $889.64 \pm 18.29^{\mathrm{a}}$ \\
Hatching $(\%)$ & $45.68 \pm 7.71^{\mathrm{a}}$ & $61.00 \pm 3.97^{\mathrm{a}}$ & $78.65 \pm 3.60^{\mathrm{a}}$ & $65.46 \pm 4.57^{\mathrm{ab}}$ \\
Larva size $(\mu \mathrm{m})$ & $3,766.77 \pm 55.26^{\mathrm{a}}$ & $3,842.58 \pm 50.55^{\mathrm{a}}$ & $3,830.29 \pm 6.72^{\mathrm{a}}$ & $45.22 \pm 6.23^{\mathrm{a}}$ \\
Larva deformity $(\%)$ & $13.81 \pm 4.59^{\mathrm{a}}$ & $8.73 \pm 2.72^{\mathrm{a}}$ & $13.85 \pm 3.42^{\mathrm{a}}$ & $3,814.88 \pm 70.50^{\mathrm{a}}$ \\
\hline
\end{tabular}

\section{DISCUSSION}

A diet containing vegetable oils was effective and resulted in satisfactory reproductive indices in Rhamdia quelen females, which suggests vegetable oils are effective and sustainable alternatives to fish oil in diets for this species. The diet containing palm oil was associated with the highest spawning rate. This positive influence may be due to the presence of tocopherol and tocotrienol in palm oil, which are potent anti-oxidants acting against the free radicals that catalyse lipid peroxidation thus protecting the cell membranes $(\mathrm{Ng} \&$ Wang, 2011; Abozaid et al., 2012; Aysi \& Zhao, 2014) and reducing the oxidative stress after hormone induction.

The relative and absolute fecundity observed in this study were superior to those reported by Tessaro et al. (2014), who analyzed various digestible energy levels for South American catfish females fed soybean oil at the same age of our study. Tessaro et al. (2014) reported means of 51,000 to 71,000 oocytes released per female and a relative fecundity rate of 246-301 oocytes $\mathrm{g}^{-1}$. In the present study, the mean number of oocytes released per female was 92,000 (palm oil) to 111,000 (soybean oil), and relative fecundity rate was 289 at 323 oocytes $\mathrm{g}^{-1}$.

The lower fertilization and hatching rates of females fed soybean oil may be due to the more advanced stage of maturation of these females at the time of hormone induction, resulting in over-ripening. This process can be seen when oocytes remain too long in the abdominal cavity and thus lack oxygen, leading to tissue degeneration and metabolic changes (Lahnsteiner et al., 2008). This process of super-maturation is commonly observed in native Brazilian species, as in hormone- induced South American catfish (Romagosa et al., 2012). In super-maturation, fertilization rates are compromised, and fish may be infertile (Lahnsteiner et al., 2008).

The higher quantity of oleic acid observed in the ovaries and oocytes of the palm oil group may explain the fertilization rate similar to that obtained with the fish oil diet, as this fatty acid is essential for normal embryo development in fish (Fernandez-Palacios et al., 1997). This energy came from the mitochondrial $\beta$ oxidation of saturated (16:0) and monosaturated (18: 1n-9) fatty acids, which are preferred substrates for energy production in fish (Henderson, 1996). In general, evidence indicates that $\beta$-oxidation of fatty acids in units is essential for oocyte maturation and early stages of embryo development (Dunning \& Robker, 2012).

Similar results have been reported by Sink \& Lochmann (2008), who used poultry fat in the diet of channel catfish Ictalurus punctatus and recommended it as a source of saturated fat to increase production and quality of eggs and larvae. In South American catfish, higher levels of saturated fatty acid in the diet (pork fat) resulted in normal embryo and larval development (Parra et al., 2008).

Although some studies suggest that the levels of n3 fatty acids should be lower than n- 6 fatty acids in diets of freshwater fish. Sargent et al. (2002) observed greater conversion for $\mathrm{n}-3$ production, especially DHA, than for n-6 in ovary and oocyte. This is in agreement with Coldebella et al. (2013) and corroborates the potential for fatty acids to be mobilized from the tissues to the oocytes (Tocher, 2003).

Although the palm oil diet resulted in low levels of linolenic acid (18:3n-3), South American catfish fema- 
Table 5. Mean \pm standard error of the fatty acid content (\% of total FA) in ovaries of Rhamdia quelen, fed with diets containing different lipid sources, soybean, palm, marine fish and the blend of three oils (MIX), obtained from ovaries from two females per cage (material collected in February). Different letters in a row indicate significant difference $(P<0.05)$. SO: diet containing soybean oil; PO: diet containing refined palm oil; FO: diet containing marine fish oil; MIX: diet containing a combination of the three oils.

\begin{tabular}{|c|c|c|c|c|}
\hline \multirow{2}{*}{ Fatty acid (\%) } & \multicolumn{4}{|c|}{ Diets } \\
\hline & SO & $\mathrm{PO}$ & FO & MIX \\
\hline C14:0 & $0.92 \pm 0.06^{\mathrm{c}}$ & $1.07 \pm 0.06^{\mathrm{bc}}$ & $1.73 \pm 0.04^{\mathrm{a}}$ & $1.15 \pm 0.02^{\mathrm{a}}$ \\
\hline $\mathrm{C} 15: 0$ & $0.18 \pm 0.00^{\mathrm{bc}}$ & $0.15 \pm 0.01^{\mathrm{c}}$ & $0.33 \pm 0.02^{\mathrm{a}}$ & $0.23 \pm 0.01^{\mathrm{b}}$ \\
\hline C16:0 & $4.70 \pm 0.28^{c}$ & $29.32 \pm 0.38^{\mathrm{a}}$ & $27.91 \pm 0.20^{b}$ & $27.59 \pm 0.26^{\mathrm{b}}$ \\
\hline C17:0 & $0.23 \pm 0.02^{\mathrm{b}}$ & $0.16 \pm 0.00^{c}$ & $0.38 \pm 0.04^{\mathrm{a}}$ & $0.26 \pm 0.01^{\mathrm{b}}$ \\
\hline C18:0 & $9.99 \pm 0.27^{\mathrm{a}}$ & $9.44 \pm 0.40^{\mathrm{a}}$ & $9.29 \pm 0.31^{\mathrm{a}}$ & $9.20 \pm 0.24^{\mathrm{a}}$ \\
\hline C 20:0 & $0.10 \pm 0.01^{\mathrm{ab}}$ & $0.08 \pm 0.00^{\mathrm{b}}$ & $0.11 \pm 0.01^{\mathrm{a}}$ & $0.09 \pm 0.00^{\mathrm{ab}}$ \\
\hline$\Sigma$ Saturated & $36.14 \pm 0.41^{\mathrm{c}}$ & $40.24 \pm 0.40^{\mathrm{a}}$ & $39.77 \pm 0.27^{\mathrm{ab}}$ & $38.54 \pm 0.25^{\mathrm{b}}$ \\
\hline $\mathrm{C} 16: 1$ & $1.07 \pm 0.15^{\mathrm{b}}$ & $1.55 \pm 0.01^{\mathrm{b}}$ & $2.74 \pm 0.21^{\mathrm{a}}$ & $1.68 \pm 0.11^{\mathrm{b}}$ \\
\hline C $17: 1$ & $0.06 \pm 0.00^{\mathrm{c}}$ & $0.06 \pm 0.00^{\mathrm{c}}$ & $0.22 \pm 0.01^{\mathrm{a}}$ & $0.10 \pm 0.00^{\mathrm{b}}$ \\
\hline $\mathrm{C} 18: \ln 7$ & $2.53 \pm 0.11^{\mathrm{bc}}$ & $2.36 \pm 0.17^{\mathrm{c}}$ & $3.54 \pm 0.13^{\mathrm{a}}$ & $2.94 \pm 0.09^{\mathrm{b}}$ \\
\hline C18:1n9 & $20.57 \pm 0.36^{b c}$ & $25.58 \pm 0.34^{\mathrm{a}}$ & $19.67 \pm 0.38^{c}$ & $21.55 \pm 0.17^{b}$ \\
\hline C20: $\ln 9$ & $0.77 \pm 0.44^{\mathrm{b}}$ & $1.13 \pm 0.06^{\mathrm{a}}$ & $1.10 \pm 0.06^{\mathrm{a}}$ & $1.05 \pm 0.03^{\mathrm{a}}$ \\
\hline $\mathrm{C} 24: \ln 9$ & $1.35 \pm 0.04^{\mathrm{ab}}$ & $1.06 \pm 0.04^{\mathrm{c}}$ & $1.40 \pm 0.06^{\mathrm{a}}$ & $1.25 \pm 0.04^{\mathrm{b}}$ \\
\hline$\sum$ Mono-unsaturated & $26.37 \pm 0.53^{\mathrm{c}}$ & $31.77 \pm 0.27^{\mathrm{a}}$ & $28.67 \pm 0.62^{\mathrm{b}}$ & $28.57 \pm 0.17^{\mathrm{b}}$ \\
\hline C18:3n3 & $0.45 \pm 0.07^{\mathrm{a}}$ & $0.19 \pm 0.01^{\mathrm{c}}$ & $0.36 \pm 0.04^{\mathrm{b}}$ & $0.31 \pm 0.02^{\mathrm{b}}$ \\
\hline C20:3n 3 & $0.34 \pm 0.02^{\mathrm{a}}$ & $0.20 \pm 0.01^{b}$ & $0.29 \pm 0.01^{\mathrm{a}}$ & $0.30 \pm 0.02^{\mathrm{a}}$ \\
\hline C20:5n3 (EPA) & $0.52 \pm 0.04^{\mathrm{c}}$ & $0.51 \pm 0.04^{\mathrm{c}}$ & $1.30 \pm 0.05^{\mathrm{a}}$ & $0.77 \pm 0.03^{b}$ \\
\hline C22:6n3 (DHA) & $9.25 \pm 0.36^{\mathrm{c}}$ & $8.89 \pm 0.30^{c}$ & $13.86 \pm 0.43^{\mathrm{a}}$ & $11.53 \pm 0.09^{\mathrm{b}}$ \\
\hline $\mathrm{C} 18: 2 \mathrm{n} 6$ & $12.09 \pm 0.55^{\mathrm{a}}$ & $6.77 \pm 0.24^{\mathrm{c}}$ & $7.31 \pm 0.38^{\mathrm{bc}}$ & $8.79 \pm 0.31^{\mathrm{b}}$ \\
\hline C18:3n6 & $2.31 \pm 0.29^{\mathrm{a}}$ & $1.05 \pm 0.08^{b}$ & $0.68 \pm 0.06^{\mathrm{b}}$ & $1.11 \pm 0.09^{\mathrm{b}}$ \\
\hline C20:2 & $2.39 \pm 0.19^{\mathrm{a}}$ & $1.58 \pm 0.05^{\mathrm{b}}$ & $1.60 \pm 0.09^{b}$ & $2.07 \pm 0.08^{\mathrm{a}}$ \\
\hline C20:3n6 & $5.65 \pm 0.27^{\mathrm{a}}$ & $4.86 \pm 0.07^{b}$ & $3.17 \pm 0.08^{c}$ & $4.46 \pm 0.10^{\mathrm{b}}$ \\
\hline C20:4n6 (ARA) & $3.06 \pm 0.14^{\mathrm{a}}$ & $2.61 \pm 0.03^{\mathrm{ab}}$ & $1.78 \pm 0.10^{\mathrm{c}}$ & $2.32 \pm 0.12^{\mathrm{b}}$ \\
\hline C22:4n6 & $0.53 \pm 0.06^{\mathrm{a}}$ & $0.38 \pm 0.02^{\mathrm{b}}$ & $0.53 \pm 0.02^{\mathrm{a}}$ & $0.44 \pm 0.02^{\mathrm{a}}$ \\
\hline C 22:5n6 & $0.95 \pm 0.10^{\mathrm{a}}$ & $0.85 \pm 0.04^{\mathrm{ab}}$ & $0.54 \pm 0.01^{\mathrm{c}}$ & $0.66 \pm 0.04^{\mathrm{bc}}$ \\
\hline$\Sigma C 18$ & $14.85 \pm 0.82^{\mathrm{a}}$ & $8.00 \pm 0.25^{\mathrm{c}}$ & $8.36 \pm 0.42^{\mathrm{bc}}$ & $10.21 \pm 0.39^{\mathrm{b}}$ \\
\hline$\Sigma C 20-22$ & $22.70 \pm 0.80^{\mathrm{a}}$ & $19.90 \pm 0.24^{\mathrm{b}}$ & $23.07 \pm 0.53^{\mathrm{a}}$ & $22.57 \pm 0.23^{\mathrm{a}}$ \\
\hline$\Sigma$ Poly-unsaturated & $37.56 \pm 0.08^{\mathrm{a}}$ & $27.91 \pm 0.38^{\mathrm{c}}$ & $31.43 \pm 0.86^{\mathrm{b}}$ & $32.78 \pm 0.21^{\mathrm{b}}$ \\
\hline n3 & $10.57 \pm 0.40^{\mathrm{c}}$ & $9.80 \pm 0.30^{\mathrm{c}}$ & $15.82 \pm 0.46^{\mathrm{a}}$ & $12.92 \pm 0.10^{\mathrm{b}}$ \\
\hline$+n 6$ & $24.59 \pm 0.54^{\mathrm{a}}$ & $16.53 \pm 0.24^{b}$ & $14.01 \pm 0.47^{\mathrm{c}}$ & $17.79 \pm 0.24^{b}$ \\
\hline $\mathrm{n} 3 / \mathrm{n} 6$ & $0.43 \pm 0.02^{\mathrm{d}}$ & $0.59 \pm 0.02^{\mathrm{c}}$ & $1.13 \pm 0.03^{\mathrm{a}}$ & $0.73 \pm 0.01^{\mathrm{b}}$ \\
\hline DHA/EPA & $18.07 \pm 1.74^{\mathrm{a}}$ & $17.56 \pm 1.03^{\mathrm{a}}$ & $10.70 \pm 0.31^{\mathrm{b}}$ & $14.98 \pm 0.54^{\mathrm{a}}$ \\
\hline EPA/ARA & $0.17 \pm 0.01^{\mathrm{c}}$ & $0.20 \pm 0.03^{\mathrm{c}}$ & $0.73 \pm 0.03^{\mathrm{a}}$ & $0.34 \pm 0.02^{\mathrm{b}}$ \\
\hline
\end{tabular}

les converted this into poly-unsaturated fatty acids including EPA and DHA, stored primarily in the gonads and oocytes. Anido et al. (2015) reported a higher quantity of EPA (2.3\%) and DHA (7.3\%) observed in mature ovaries of wild $R$. quelen than those observed in this study.

Despite low levels of linoleic acid in palm oil diets, females of this group appeared to efficiently convert it to ARA, as the quantity of this fatty acid in ovary and oocytes was similar to that of females fed soybean oil. The conversion may have been enhanced by lower levels of linolenic acid, enabling the $\Delta-6$ desaturase enzyme to convert linoleic acid into ARA ( $\mathrm{Ng} \&$ Wang, 2011). This variable ability of desaturation and elongation in fish may be related to different age stages (Bell et al., 2001) and water temperature (Agaba et al., 2005). However, Coldebella et al. (2013) observed lower levels of EPA and DHA in the ovaries of $R$. quelen, compared with the present study. Such difference could be explained by our use of salmon meal in the diet, with higher levels of C18: $3 n-3$, while Coldebella et al. (2013) used pork meat and bone meal in their diet. 
Table 6. Fatty acid profile (\%) in oocytes of Rhamdia quelen females fed diets containing different lipid sources, soybean, palm, marine fish and the blend of three oils (MIX). Mean \pm standard error of results obtained from a pool of oocytes from five females per treatment. Different letters in a row indicate significant difference $(P<0.05)$. SO: diet containing soybean oil; PO: diet containing refined palm oil; FO: diet containing marine fish oil; MIX: diet containing a combination of the three oils.

\begin{tabular}{|c|c|c|c|c|}
\hline \multirow{2}{*}{ Fatty acid (\%) } & \multicolumn{4}{|c|}{ Diets } \\
\hline & $\mathrm{SO}$ & $\mathrm{PO}$ & FO & MIX \\
\hline C14:0 & $1.1 \pm 0.03^{\mathrm{c}}$ & $1.37 \pm 0.04^{\mathrm{b}}$ & $1.76 \pm 0.04^{\mathrm{a}}$ & $1.39 \pm 0.08^{\mathrm{b}}$ \\
\hline C15:0 & $0.18 \pm 0.01^{\mathrm{bc}}$ & $0.15 \pm 0.00^{c}$ & $0.33 \pm 0.01^{\mathrm{a}}$ & $0.22 \pm 0.01^{\mathrm{b}}$ \\
\hline C16:0 & $25.18 \pm 0.16^{\mathrm{c}}$ & $30.08 \pm 0.10^{\mathrm{a}}$ & $27.91 \pm 0.39^{\mathrm{b}}$ & $27.93 \pm 0.38^{\mathrm{b}}$ \\
\hline C17:0 & $0.22 \pm 0.00^{\mathrm{c}}$ & $0.16 \pm 0.00^{\mathrm{d}}$ & $0.37 \pm 0.01^{\mathrm{a}}$ & $0.26 \pm 0.01^{\mathrm{b}}$ \\
\hline C18:0 & $9.83 \pm 0.22^{\mathrm{a}}$ & $9.81 \pm 0.23^{\mathrm{a}}$ & $9.09 \pm 0.17^{\mathrm{a}}$ & $9.80 \pm 0.43^{\mathrm{a}}$ \\
\hline C 20:0 & $0.09 \pm 0.00^{\mathrm{a}}$ & $0.07 \pm 0.01^{\mathrm{a}}$ & $0.09 \pm 0.00^{\mathrm{a}}$ & $0.08 \pm 0.00^{\mathrm{a}}$ \\
\hline$\Sigma$ Saturated & $36.61 \pm 0.31^{\mathrm{c}}$ & $41.67 \pm 0.24^{a}$ & $39.56 \pm 0.37^{b}$ & $39.69 \pm 0.62^{b}$ \\
\hline C16:1 & $1.17 \pm 0.05^{\mathrm{c}}$ & $1.80 \pm 0.09^{\mathrm{b}}$ & $2.67 \pm 0.14^{\mathrm{a}}$ & $1.76 \pm 0.18^{\mathrm{b}}$ \\
\hline C $17: 1$ & $0.07 \pm 0.00^{c}$ & $0.07 \pm 0.01^{\mathrm{c}}$ & $0.18 \pm 0.01^{\mathrm{a}}$ & $0.11 \pm 0.01^{\mathrm{b}}$ \\
\hline $\mathrm{C} 18: \ln 7$ & $2.44 \pm 0.09^{\mathrm{a}}$ & $2.24 \pm 0.06^{\mathrm{b}}$ & $3.64 \pm 0.11^{\mathrm{a}}$ & $2.65 \pm 0.14^{\mathrm{b}}$ \\
\hline C18:1n9 & $21.42 \pm 0.32^{\mathrm{b}}$ & $25.98 \pm 0.29^{\mathrm{a}}$ & $20.20 \pm 0.33^{\mathrm{c}}$ & $22.05 \pm 0.19^{b}$ \\
\hline$C 20: \ln 9$ & $0.79 \pm 0.03^{\mathrm{b}}$ & $1.18 \pm 0.04^{\mathrm{a}}$ & $1.13 \pm 0.03^{a}$ & $1.02 \pm 0.04^{\mathrm{a}}$ \\
\hline C24:1n9 & $1.18 \pm 0.02^{\mathrm{b}}$ & $1.05 \pm 0.02^{\mathrm{b}}$ & $1.47 \pm 0.09^{\mathrm{a}}$ & $1.23 \pm 0.02^{\mathrm{b}}$ \\
\hline$\Sigma$ Mon-unsaturated & $27.08 \pm 0.39^{c}$ & $32.33 \pm 0.37^{\mathrm{a}}$ & $29.32 \pm 0.44^{\mathrm{b}}$ & $28.85 \pm 0.27^{b}$ \\
\hline C18:2n6 & $12.21 \pm 0.27^{\mathrm{a}}$ & $6.18 \pm 0.12^{\mathrm{d}}$ & $7.28 \pm 0.14^{\mathrm{c}}$ & $8.47 \pm 0.20^{\mathrm{b}}$ \\
\hline C18:3n6 & $2.65 \pm 0.26^{\mathrm{a}}$ & $1.10 \pm 0.07^{\mathrm{b}}$ & $0.74 \pm 0.05^{\mathrm{b}}$ & $1.34 \pm 0.06^{\mathrm{b}}$ \\
\hline C18:3n 3 & $0.46 \pm 0.02^{\mathrm{a}}$ & $0.18 \pm 0.01^{\mathrm{c}}$ & $0.33 \pm 0.01^{\mathrm{b}}$ & $0.32 \pm 0.01^{\mathrm{b}}$ \\
\hline C20:2 & $2.40 \pm 0.13^{\mathrm{a}}$ & $1.45 \pm 0.03^{\mathrm{c}}$ & $1.67 \pm 0.09^{\mathrm{bc}}$ & $1.84 \pm 0.04^{\mathrm{b}}$ \\
\hline C20:3n6 & $5.50 \pm 0.11^{\mathrm{a}}$ & $4.57 \pm 0.05^{\mathrm{b}}$ & $3.29 \pm 0.09^{c}$ & $4.58 \pm 0.06^{\mathrm{b}}$ \\
\hline C20:4n6 (ARA) & $2.74 \pm 0.08^{\mathrm{a}}$ & $2.53 \pm 0.05^{\mathrm{ab}}$ & $1.81 \pm 0.10^{\mathrm{c}}$ & $2.39 \pm 0.04^{b}$ \\
\hline $\mathrm{C} 20: 3 \mathrm{n} 3$ & $0.35 \pm 0.02^{\mathrm{a}}$ & $0.20 \pm 0.01^{\mathrm{c}}$ & $0.28 \pm 0.01^{\mathrm{b}}$ & $0.28 \pm 0.01^{\mathrm{b}}$ \\
\hline C20:5n3 (EPA) & $0.49 \pm 0.04^{\mathrm{c}}$ & $0.42 \pm 0.01^{\mathrm{c}}$ & $1.24 \pm 0.07^{\mathrm{a}}$ & $0.69 \pm 0.04^{\mathrm{b}}$ \\
\hline $\mathrm{C} 22: 4 \mathrm{n} 6$ & $0.43 \pm 0.02^{\mathrm{a}}$ & $0.40 \pm 0.01^{\mathrm{a}}$ & $0.50 \pm 0.01^{\mathrm{a}}$ & $0.47 \pm 0.06^{\mathrm{a}}$ \\
\hline C $22: 5 n 6$ & $0.79 \pm 0.07^{\mathrm{a}}$ & $0.96 \pm 0.05^{\mathrm{a}}$ & $0.54 \pm 0.02^{\mathrm{b}}$ & $0.72 \pm 0.05^{\mathrm{ab}}$ \\
\hline C22:6n3 (DHA) & $8.05 \pm 0.33^{c}$ & $7.93 \pm 0.14^{\mathrm{c}}$ & $13.32 \pm 0.39^{\mathrm{a}}$ & $10.18 \pm 0.31^{\mathrm{b}}$ \\
\hline $9.25 \pm 0.36^{\mathrm{c}}$ & $8.89 \pm 0.30^{c}$ & $13.86 \pm 0.43^{\mathrm{a}}$ & $11.53 \pm 0.09^{\mathrm{b}}$ & $9.25 \pm 0.36^{\mathrm{c}}$ \\
\hline$\Sigma C 18$ & $15.33 \pm 0.48^{\mathrm{a}}$ & $7.46 \pm 0.17^{\mathrm{c}}$ & $8.35 \pm 0.17^{\mathrm{c}}$ & $10.13 \pm 0.24^{b}$ \\
\hline$\Sigma C 20-22$ & $20.76 \pm 0.68^{\mathrm{ab}}$ & $18.46 \pm 0.23^{b}$ & $22.64 \pm 0.71$ & $19.88 \pm 0.65^{\mathrm{b}}$ \\
\hline$\Sigma$ Poly-unsaturated & $36.08 \pm 0.33^{\mathrm{a}}$ & $25.92 \pm 0.21^{\mathrm{c}}$ & $30.99 \pm 0.80^{\mathrm{b}}$ & $31.32 \pm 0.50^{\mathrm{b}}$ \\
\hline n3 & $9.35 \pm 0.34^{\mathrm{c}}$ & $8.72 \pm 0.13^{c}$ & $15.17 \pm 0.47^{\mathrm{a}}$ & $11.47 \pm 0.34^{\mathrm{b}}$ \\
\hline n6 & $24.33 \pm 0.27^{\mathrm{a}}$ & $15.74 \pm 0.15^{\mathrm{c}}$ & $14.16 \pm 0.30^{\mathrm{d}}$ & $18.00 \pm 0.16^{b}$ \\
\hline $\mathrm{n} 3 / \mathrm{n} 6$ & $0.39 \pm 0.02^{\mathrm{d}}$ & $0.55 \pm 0.01^{\mathrm{c}}$ & $1.07 \pm 0.02^{\mathrm{a}}$ & $0.64 \pm 0.02^{\mathrm{b}}$ \\
\hline DHA/EPA & $16.91 \pm 1.29^{\mathrm{ab}}$ & $18.93 \pm 0.55^{\mathrm{a}}$ & $10.82 \pm 0.35^{\mathrm{c}}$ & $14.78 \pm 0.50^{\mathrm{b}}$ \\
\hline EPA/ARA & $0.18 \pm 0.01^{\mathrm{c}}$ & $0.17 \pm 0.01^{\mathrm{c}}$ & $0.68 \pm 0.02^{\mathrm{a}}$ & $0.29 \pm 0.01^{\mathrm{b}}$ \\
\hline
\end{tabular}

As observed by several authors, adequate ARA concentrations in the diet are important to stimulate oocyte maturation (Pérez et al., 2007; Norambuena et al., 2013). Linoleic acid is a precursor of ARA via the action of the $\Delta$-6-desaturase. However, high levels of ARA may cause harmful effects in some species, as verified by Furuita et al. (2007), who found the hatching rate and larval development of Anguilla japonica were compromised.

Ovaries and eggs varied in DHA/EPA, EPA/ARA and $\mathrm{n} 3 / \mathrm{n} 6$ ratios among treatments. Liang et al. (2014) suggested that optimum dietary ratios of these fatty acids are necessary to ensure the quality of the eggs and larvae but can be species-dependent. We found ovaries and eggs to have low proportions of EPA/ARA, which did not affect the reproductive performance of $R$. quelen females.

Hormone treatment may affect the synthesis of vitellogenin and fatty acid of $R$. quelen oocytes (Żarski et al., 2012). In the present study, the fatty acid profile of ovaries and oocytes was similar; however, oocyte DHA levels were lower than was observed in the 
ovaries, also reported in hormonally induced milkfish Chanos chanos (Ako et al., 1994).

Research on broodstock nutrition has highlighted the use of palm oil as a potential partial or complete replacement for fish oil. Although it does not provide high quantities of poly-unsaturated fatty acids, especially $\mathrm{n}-3$, it provides a superior source of energy for reproductive success ( $\mathrm{Ng} \&$ Wang, 2011).

The diets containing vegetable oils alone and in combination with fish oil, fed to females for eleven months produced satisfactory rates of fecundity and fertilization in the first reproductive cycle. The higher quantity of n-6 fatty acids soybean oil possibly accelerated ovarian development, resulting in lower fertilization, although accurate prediction of the spawning period could resolve it. Fatty acids in the diet influenced the profile of gonads and oocytes, with higher concentrations of DHA observed, indicating that $R$. quelen can be synthesized and deposit LC-PUFAS in the ovaries and eggs from the 18-carbon precursor. Such deposition could be related to the salmon meal (20\%), which contains high amounts of these fatty acids, in the formulated diet. The vegetable sources used are suitable for broodstock nutrition and, as reported by other authors (Shiranee \& Natarajan, 1996; $\mathrm{Ng} \&$ Wang, 2011) palm oil could be used as a replacement to fish oil.

\section{ACKNOWLEDGMENTS}

This study was funded by the Research Aid (Auxílio à Pesquisa) from FAPESP (2012/23089-4) and CNPq through a Ph.D. grant (142751/2011-1). The authors would like to thank the Instituto de Pesquisa em Aquicultura Ambiental-Unioeste/PR for providing the infrastructure, Nicoluzzi and Agropalma industries for donating the marine fish oil and the refined palm oil.

\section{REFERENCES}

Abozaid, H., Wessels, S. \& Hoerstgen-Schwark, G. 2012. Elevated temperature applied during gonadal transformation leads to male bias in Zebrafish (Danio rerio). Sexual Development, 6: 201-209.

Agaba, M.K., Tocher, D.R., Zheng, X., Dickson, C.A., Dick, J.R. \& Teale, A.J. 2005. Cloning and functional characterization of polyunsaturated fatty acid elongases of marine and freshwater teleost fish. Comparative Biochemistry and Physiology - Part B: Biochemical and Molecular Biology, 142: 342-352.

Ako, H., Tamaru, C.S. \& Lee, C.S. 1994. Chemical and physical differences in milkfish (Chanos chanos) eggs from natural and hormonally induced spawns. Aquaculture, 127: 157-167.

Anido, R.V., Zaniboni-Filho, E., Garcia, A.S., Baggio, S.R. \& Fracalossi, D.M. 2015. Characterization of the ovary fatty acids composition of Rhamdia quelen (Quoy \& Gaimard) (Teleostei: Siluriformes), throughout their reproductive cycle. Neotropical Ichthyology, 13: 453-460.

Aysi, C.L. \& Zhao, J.L. 2014. Recent development in the use of palm oil in aquaculture feeds a review. International Journal of Scientific \& Technology Research, 3: 259-264.

Babalola, T.O., Apata, D.F., Omotosho, J.S. \& Adebayo, M. 2011. Differential effects of dietary lipids on growth performance, digestibility, fatty acid composition and histology of African catfish (Heterobranchus longifilis) fingerlings. Food and Nutrition Sciences, 2: 11-21.

Bell, J.G. \& Sargent, J.R. 2003. Arachidonic acid in aquaculture feeds: current status and future opportunities. Aquaculture, 218: 491-499.

Bell, J.G., McEvoy, J., Tocher, D.R., McGhee, F., Campbell, P.J. \& Sargent, J.R. 2001. Replacement of fish oil with rapeseed oil in diets of Atlantic salmon (Salmo salar) affects tissue lipid compositions and hepatocyte fatty acid metabolism. The Journal of Nutrition, 131: 1535-1543.

Bligh, E.G. \& Dyer, W.J. 1959. A rapid method of total lipid extraction and purification. Canadian Journal of Biochemistry and Physiology, 37: 911-917.

Bombardelli, R.A., Mörschbächer, E.F., Campagnolo, R., Sanches, E.A. \& Syperreck, M.A. 2006. Dose inseminante para fertilização artificial de ovócitos de jundiá cinza, Rhamdia quelen (Quoy \& Gaimardm, 1824). Revista Brasileira de Zootecnia, 35: 1251-1257.

Brown, M.B. \& Forsythe, B.F. 1974. Robust test for the equality of variances. Journal of the American Statistical Association, 69: 364-367.

Coldebella, I.J., Emanuelli, T., Veiverberg, C.A., Pretto, A., Rossato, S., Ferreira, D., Barcellos, L.J.G. \& Neto, J.R. 2013. Effect of different dietary lipid levels on the reproduction of Rhamdia quelen (Quoy and Gaimard, 1824). Aquaculture Nutrition, 19: 751-764.

Darling, D.A. 1957. The Kolmogorov-Smirnov, Cramervon mises tests. Annals of Mathematical Statistics, 28: 823-838.

De Amorim, M.P., Gomes, B.V.C., Martins, Y.S., Sato, Y., Rizzo, E. \& Bazzoli, N. 2009. Early development of the silver catfish Rhamdia quelen (Quoy \& Gaimard, 1824) (Pisces: Heptapteridae) from the São Francisco River Basin, Brazil. Aquaculture Research, 40: 172-180. 
Dunning, K.R. \& Robker, R.L. 2012. Promoting lipid utilization with L-carnitine to improve oocyte quality. Animal Reproduction Science, 134: 69-75.

Fernandez-Palacios, H., Izquierdo, M., Robaina, L., Valencia, A. \& Salhi, M. 1997. The effect of dietary protein and lipid from squid and fish meals on egg quality of broodstock for gilthead seabream (Sparus aurata). Aquaculture, 148: 233-246.

Firestone, D. 2009 American oil chemists' society official methods and recommended practices. AOCS Press, Illinois.

Firestone, D. 2014. Official methods and recommended practices of the AOCS. AOCS Press, Illinois.

Furuita, H., Hori, K., Suzuki, Sugita, T. \& Yamamoto, T. 2007. Effect of $n-3$ and $n-6$ fatty acids in broodstock diet on reproduction and fatty acid composition of broodstock and eggs in the Japanese eel Anguilla japonica. Aquaculture, 267: 55-61.

Ghiraldelli, L., Machado, C. \& Fracalossi, D.M. 2007. Desenvolvimento gonadal do jundiá, Rhamdia quelen (Teleostei, Siluriformes), em viveiros de terra, na região sul do Brasil. Acta Scientiarum, 29: 349-356.

Gomes, L. de C., Golombieski, J.I., Gomes, A.R.C. \& Baldisserotto, B. 2000. Biologia do jundiá Rhamdia quelen (Teleostei, Pimelodidae). Ciência Rural, 30: 179-185.

Henderson, R.J. 1996. Fatty acid metabolism in freshwater fish with particular reference to polyunsaturated fatty acids. Archiv fur Tierernahrung, 49: 5-22.

Horwitz, W., Latimer, J.R. \& George, W. 2005. Official methods of analysis of the Association of Official Analytical Chemists. AOAC, Maryland.

Ittzés, I., Szabó, T., Kronbauer, E.C. \& Urbányi, B. 2015. Ovulation induction in jundiá (Rhamdia quelen, Heptapteridae) using carp pituitary extract or salmon $\mathrm{GnRH}$ analog combined with dopamine receptor antagonists. Aquaculture Research, 46: 2924-2928.

Izquierdo, M.S., Fernández-Palacios, H. \& Tacon, A.G.J. 2001. Effect of broodstock nutrition on reproductive performance of fish. Aquaculture, 197: 25-42.

Koroleff, F. 1976. Determination of ammonia. In: Grashoff, E. \& Kremmling, E. (Eds.). Methods of seawater analysis. Wiley-VCH, Weinhein, pp. 126133.

Lahnsteiner, F., Soares, F., Ribeiro, L. \& Dinis, M. 2008. Egg quality determination in teleost fish. In: Cabrita, E. \& Herráez, P. (Eds.). Methods in reproductive aquaculture. CRC Press, Florida, pp. 149-182.

Liang, M.Q., Lu, Q.K., Qian, C., Zheng, K.K. \& Wang, X.X. 2014. Effects of dietary n-3 to $n-6$ fatty acid ratios on spawning performance and larval quality in tongue sole Cynoglossus semilaevis. Aquaculture Nutrition, 20: 79-89.
Navas, J.M., Mananos, E., Thrush, M., Ramos, J., Zanuy, S., Carrillo, M., Zohar, Y. \& Bromage, N. 1998. Effect of dietary lipid composition on vitellogenin, 17 betaestradiol and gonadotropin plasma levels and spawning performance in captive sea bass (Dicentrarchus labrax L). Aquaculture, 165: 65-79.

Ng, W.K. \& Wang, Y. 2011. Inclusion of crude palm oil in the broodstock diets of female Nile tilapia, Oreochromis niloticus, resulted in enhanced reproductive performance compared to broodfish fed diets with added fish oil or linseed oil. Aquaculture, 314: 122-131.

Norambuena, F., Morais, S., Estévez, A., Bell, J.G., Tocher, D.R., Navarro, J.C., Cerdà, J. \& Duncan, N. 2013. Dietary modulation of arachidonic acid metabolism in senegalese sole (Solea Senegalensis) broodstock reared in captivity. Aquaculture, 372: 8088.

Parra, J.E.G., Radünz-Neto, J., Veiverberg, C.A., Lazarri, R., Bergamin, G.T., Pedron, F.A., Rossato, S. \& Sutili, F.J. 2008. Alimentação de fêmeas de jundiá com fontes lipídicas e sua relação com o desenvolvimento embrionário e larval. Ciência Rural, 38: 2011-2017.

Pérez, M., Rodríguez, C., Cejas, J., Martín, M., Jerez, S. \& Lorenzo, A. 2007. Lipid and fatty acid content in wild white seabream (Diplodus sargus) broodstock at different stages of the reproductive cycle. Comparative Biochemistry and Physiology - Part B: Biochemical and Molecular Biology, 146: 187-196.

Romagosa, E., Bittencourt, F. \& Boscolo, W.R. 2012. Nutrição e alimentação de reprodutores. In: Fracalossi, J.E.P. (Ed.). Nutriaqua: nutrição e alimentação de espécies de interesse para a aquicultura brasileira. Sociedade Brasileira de Biologia Aquática, Florianopólis, pp. 167-184.

Sanches, E.A., Bombardelli, R.A., Marcos, R.M., Neumann, G., Rebechi de Toledo, C.P. \& Romagosa, E. 2010. Sperm motility of Rhamdia quelen studied using computer-assisted analysis by open-source software. Aquaculture Research, 42: 153-156.

Sargent, J.R., Tocher, D.R. \& Bell, J.G. 2002. The lipids. In: Halver, J.E \& Hardy, R.W. (Eds.) Fish nutrition. Academic Press, Cambridge, pp. 181-257.

Sargent, J., Bell, G., McEvoy, L., Tocher, D. \& Estevez, A. 1999. Recent developments in the essential fatty acid nutrition of fish. Aquaculture, 177: 191-199.

Shiranee, P. \& Natarajan, R. 1996. Crude palm oil it is a source of carotenoids and tocopherols to enhance reproductive potential in pearlspot Etroplus suratensis (Bloch). Asian Fisheries Society, 9: 35-44.

Sink, T.D. \& Lochmann, R.T. 2008. Effects of dietary lipid source and concentration on channel catfish (Ictalurus punctatus) egg biochemical composition, egg and fry production, and egg and fry quality. Aquaculture, 283: 68-76. 
Tessaro, L., de Toledo, C.P.R., Neumann, G., Krause, R.A., Meurer, F., Natali, M.R.M. \& Bombardelli, R.A. 2014. Animal performance and reproductive aspects of female Rhamdia quelen fed on different levels of digestible energy. Aquaculture Research, 45: 14251433.

Tocher, D.R. 2003. Metabolism and functions of lipids and fatty acids in teleost fish. Reviews in Fisheries Science, 11: 107-184.

Turchini, G.M., Francis, D.S. \& de Silva, S.S. 2006. Fatty acid metabolism in the freshwater fish Murray cod (Maccullochella peelii peelii) deduced by the wholebody fatty acid balance method. Comparative Biochemistry and Physiology - Part B: Biochemical and Molecular Biology, 144: 110-118.

Turchini, G.M., Torstensen, B.E. \& Ng, W.K. 2009. Fish oil replacement in finfish nutrition. Reviews in Aquaculture, 1: 10-57.

Received: 14 August 2018; Accepted: 23 January 2019
Vargas, R.J., Garcia, A.S., Baggio, S.R., Cargnin-Ferreira, E. \& Fracalossi, D.M. 2014. A combination of plant oils promotes the adequate growth of the freshwater catfish Rhamdia quelen (Quoy \& Gaimard 1824). Aquaculture Research, 46: 3046-3055.

Żarski, D., Krejszeff, S., Horváth, Á., Bokor, Z., Palińska, K., Szentes, K., Łuczyńska, J., Targońska, K., Kupren, K. \& Urbányi, B. 2012. Dynamics of composition and morphology in oocytes of Eurasian perch, Perca fluviatilis L., during induced spawning. Aquaculture, 364: 103-110.

Zenebon, O. \& Pascuet, N. 2005. Métodos físico-químicos para análise de alimentos. Ministério da Saúde, Instituto Adolfo Lutz, São Paulo.

Zhang, M.Z., Li, G.L., Zhu, C.H. \& Deng, S.P. 2013. Effects of fish oil on ovarian development in spotted scat (Scatophagus argus). Animal Reproduction Science, 141: 90-97. 